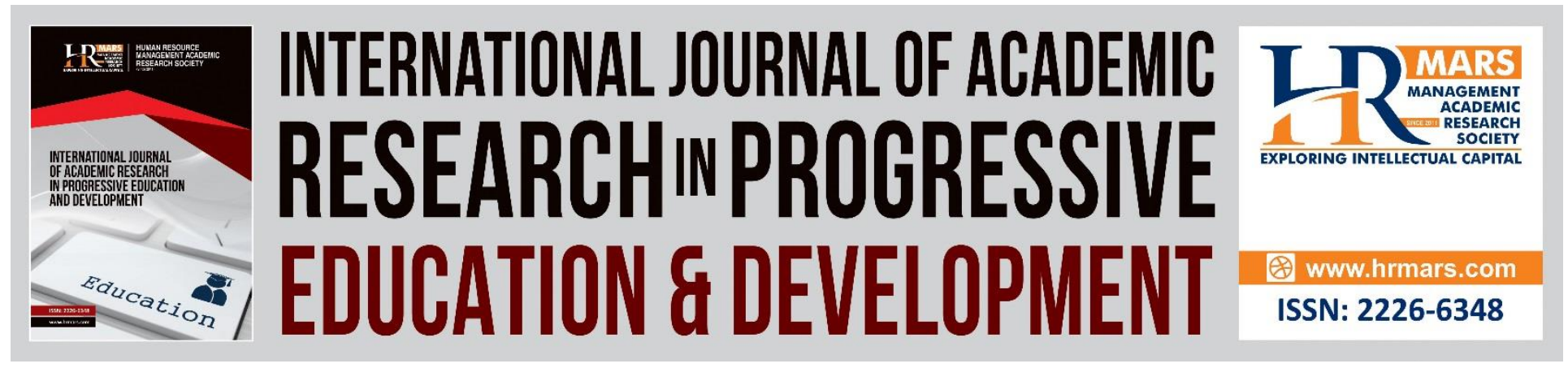

\title{
Depression, Anxiety, Stress Ratios and Job Satisfaction in Special Education Schools in Malaysia
}

\author{
Muhammad Zakwan Fikhri Bin Mohd Azizi \& Nurul-Azza Abdullah
}

To Link this Article: http://dx.doi.org/10.6007/IJARPED/v10-i1/9624

DOI:10.6007/IJARPED/v10-i1/9624

Received: 01 January 2021, Revised: 29 January 2021, Accepted: 20 February 2021

Published Online: 21 March 2021

In-Text Citation: (Azizi \& Abdullah, 2021)

To Cite this Article: Azizi, M. Z. F. B. M., \& Abdullah, N.-A. (2021). Depression, Anxiety, Stress Ratios and Job Satisfaction in Special Education Schools in Malaysia. International Journal of Academic Research in Progressive Education and Development, 10(1), 686-699.

Copyright: (C) 2021 The Author(s)

Published by Human Resource Management Academic Research Society (www.hrmars.com)

This article is published under the Creative Commons Attribution (CC BY 4.0) license. Anyone may reproduce, distribute, translate and create derivative works of this article (for both commercial and non-commercial purposes), subject to full attribution to the original publication and authors. The full terms of this license may be seen at: http://creativecommons.org/licences/by/4.0/legalcode

Vol. 10(1) 2021, Pg. 686 - 699

http://hrmars.com/index.php/pages/detail/IJARPED

JOURNAL HOMEPAGE

Full Terms \& Conditions of access and use can be found at http://hrmars.com/index.php/pages/detail/publication-ethics 


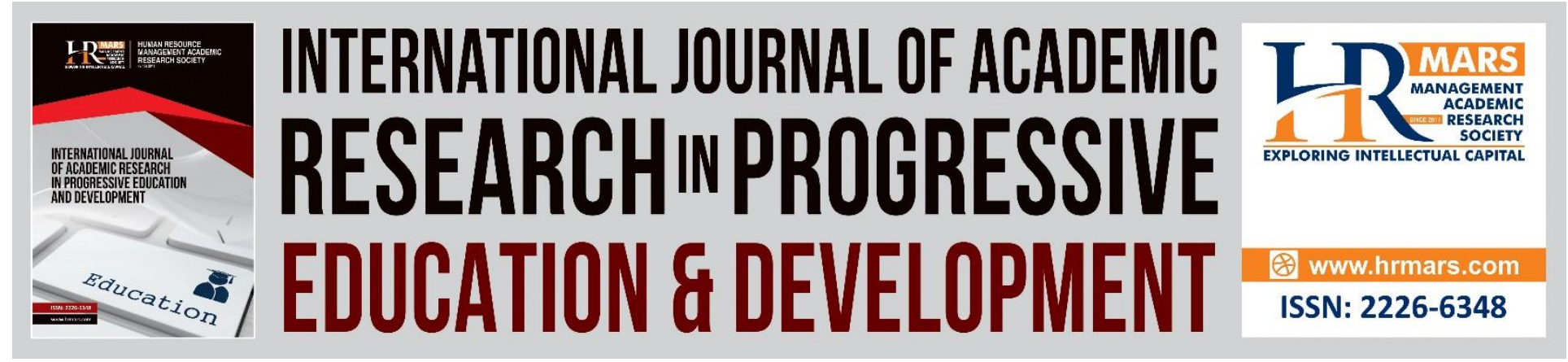

\title{
Depression, Anxiety, Stress Ratios and Job Satisfaction in Special Education Schools in Malaysia
}

\author{
Muhammad Zakwan Fikhri Bin Mohd Azizi \& Nurul-Azza Abdullah \\ Psychology Program, Center for Research in Psychology and Human Well-Being, Faculty of \\ Social Science and Humanities, The National University of Malaysia, 43600 Bangi, Selangor, \\ Malaysia
}

Email: mailto:zakwan3300@gmail.com,nurulazza@ukm.edu.my

\begin{abstract}
The study was conducted to look at the level of depression, anxiety, stress and job satisfaction among Special Education teachers in Special Education Schools around Kuala Lumpur. Mental disorders are defined as health conditions related to emotional change, depression, and posttraumatic stress. Mental retardation is often associated with difficulties and problems in dealing with social life and family activities (Parekh 2018). A total of 96 respondents consisting of teachers and assistant teachers were involved in this study. This study aimed to look at the relationship between depression, anxiety and stress on job satisfaction. Relationships were also seen in terms of age demographics, Area of residence, and duration of service to teacher job satisfaction. Differences in gender demographic factors and travel distance to work satisfaction were studied. The measurement instrument used in this study was the Depression, Anxiety and Stress Scale (DASS) survey to measure levels of depression, anxiety and stress. Meanwhile, the Job Satisfaction Survey (JSS) gauge is used to measure employee satisfaction levels. Survey data were collected and analyzed using descriptive statistics and inferential statistics methods. Descriptive statistical methods were used to describe and explain the frequency and percentage of each variable involved. Meanwhile, statistical inference methods were used to examine the relationship between depression, anxiety, stress and job satisfaction through the Pearson Correlation test. The results of this study showed there is no significant relationship between depression, anxiety and work stress and job satisfaction. This study will positively impact the Ministry of Education (MOE) on the mental health of Special Education teachers.
\end{abstract}

Keywords: Depression, Anxiety, Stress, and Job Satisfaction Among Workers

\section{Introduction}

The development of globalization today shows that organizations should be better prepared to face various problems and frustrations by employees. Problems that occur, such as employee 
turnover, absenteeism and employee dissatisfaction, are related to workplace stress. Stress issues in the workplace affect the overall performance of the organization. What is stress? Stress in the workplace refers to employees' perceptions of environmental needs that go beyond their available resources. Stress can also be interpreted as external forces or pressures that affect an individual's physical and material forces. Job stress for teachers has gained attention in western countries over the past two decades. This can be evidenced by the many stress studies that have been conducted on teachers (Kyriacou, 1987; Borg, 1990) and the various programs and workshops organized to assist teachers in dealing with occupational problems and stress (Cox et al. 1988). Calabrese (1987) showed evidence that low levels of stress are related to low teacher teaching effectiveness.

Evidence from this stressful study on teachers also shows how serious this problem is. The implications of stress are not only on teachers' well-being but also on how prolonged stress can affect this group's mental and physical health. Kinnunen (1989) claims that stress may affect teachers' work performance and teaching process.

In general, everyone has experienced feelings of stress or depression towards themselves. This stress is a part of human life. The way individuals deal with stress also varies from individual to individual. Acevedo \& Ekkekakis 2006 state that stress occurs on natural characteristics such as heredity or genetics and barriers to individuals to do something. Second, it is influenced by environmental factors such as the circumstances and situations of the individual's home and past experiences. Thus the onset of stress can be caused by internal factors and individual external factors. Lester, Nebel and Baum (1994) state that stress and anxiety experienced lead to depression. Depression is an emotional disorder that causes a person to feel prolonged sadness, fatigue, lack of energy, irritability, and interest in daily activities. It lasts for at least two weeks. The disease can affect anyone regardless of age, gender or race. Depression can last for months or even years. In understanding depression, Hawari (2000) states that depression is a feeling that is synonymous with feelings of sadness, depression, resentment, unhappiness, and suffering. Depression is one of the most common psychiatric disorders in the world. The cause of this depression is from a person's failure to achieve something very desired in his life. (Al-Kindi, 1978). This will of course cause a person to experience stress and depression because human will is not limited, while human beings are not able to fulfill all those desires.

\section{Research Problem}

The Institute of Public Health, Ministry of Health Malaysia ( $\mathrm{MOH})$ in the National Health and Morbidity Survey Report 2017 (National Health and Morbidity Survey, NHMS 2017) has conducted a mental health study on adolescents between the ages of 13 to 17 years in Malaysia using the DASS model- 21. The 2017 NHMS study showed an increase in depression and anxiety cases than the 2012 NHMS survey (Institute for Public Health, 2017). If this mental health is not taken care of and treated correctly, this will lead to a loss of productivity and a high tendency for patients to commit suicide (Schmidt, 2007). In another case, based on statistics conducted by the Psychology and Counseling Division of the Ministry of Education Malaysia (MOE) found that 4.4 percent or 2,123 out of 48,258 teachers were identified as experiencing moderately high levels of stress. This percentage rate increases every day due to various factors, including family issues, 
finances, administration, workload, lack of appreciation, lack of skills in carrying out tasks and not being trained to deal with stress. The problem of stress and depression among teachers is quite severe, where a case of depression involving a female teacher in Balik Pulau disappeared for four days (Utusan Online, 2019). The teacher suffered from stress and depression due to overwork and long-distance marriage. The teacher has to drive more than $100 \mathrm{~km}$ to go and return to school. This causes when the body does not get enough rest, stress and depression factors are more likely to spread. Here, this study of stress and depression plays a vital role in assessing teachers' stress and depression levels in the national school.

\section{Literature Review}

\section{Depression, anxiety and stress among employees}

Anxiety, depression, and stress are common problems, especially for Malaysians who need to be given attention because they will be detrimental to health and emotional disorders (Salleh \& Kadir, 2013). Various tests have been done on anxiety, depression, and stress to understand the problems that interfere with a person's well-being if not curbed from the beginning. A study was conducted by Park et al. (2008) on the relationship between work stress and depression, anxiety and stress among white-collar male workers in automotive companies. The study involved 286 male employees using the Korean Occupational Stress Scales (KOSS) and Depression Anxiety Stress Scales (DASS) questionnaires. The results showed that the symptoms of depression were $57.7 \%$, while the symptoms of anxiety were $37.7 \%$, and stress symptoms are as much as $37.7 \%$. Based on logistical regression analysis, the organizational system is the most potent factor influencing depression, while job demand strongly influences anxiety and stress. Overall, work stress positively affects depression, anxiety and stress among male employees in automotive companies. There is also a study made by Lee M. (2011) on the relationship between work stress and depression among construction workers and shows that work stress positively has a relationship with depression.

A study was made by Abdulai (2005) related to work stress and job satisfaction towards expatriate lecturers at IIUM (International Islamic University Malaysia). It was found that work stress is closely related to one's job satisfaction because it will affect the performance of university lecturers. If an individual's job satisfaction is high, work stress can be reduced because they feel comfortable and satisfied with their job. On the other hand, if there is dissatisfaction with the work that needs to be done, the individual tends to feel depressed. Therefore, one's job satisfaction also plays an essential role in overcoming work stress. A survey of staff at the University of New Zealand in New South Wales found that $82 \%$ of respondents experienced more than seven work stress conditions, and $51 \%$ experienced more than 11 work stress conditions. This study states that both high work stress and work that does not involve high stress are also associated with job dissatisfaction, psychological problems, adverse effects, apparent anxiety, absenteeism, seeing a doctor and illness, and severe physical health problems (Two, 1994).

A study conducted by Turnage and Speilberger (1991) on 30 sources of work stress with the Job Stress Survey (JSS) tested white-collar workers across factory firms comprising 68 managers, 171 engineers professionals and 69 people in the field of clerical. High levels of stress have been 
Vol. 10, No. 1, 2021, E-ISSN: 2226-6348 @ 2021 HRMARS

referred to as "lack of opportunities for progress" and "poor or inadequate supervision." The cause of individual stress that often occurs after six months is a "frequent disorder." specific period for meetings "and" facing "crises." Analytical factors on the network of causes of individual work stress have been identified into two factors: work stress and lack of support related to age, gender, level of employment, locus of control and permanent employment, and satisfaction. Stress factors such as overwork, role conflict, job satisfaction and work environment. Excessive work factor is a significant factor in stress among JKM staff.

\section{Employee Job Satisfaction}

A study was conducted by Mohd Zhafri (2011) related to the relationship between job satisfaction and organizational commitment in ALPS Malaysia SDN. BHD. Against 157 respondents using the Organizational Commitment Questionnaire "(OCR) and" Job Description Index "(JDI) questionnaire in Jengka, Pahang. Rank, working conditions, supervision and colleagues, and the relationship of organizational commitment with demographic factors such as position, gender, race, age, education, marital status, work experience and income received. The results show a significant relationship between factors demographics and job satisfaction with commitment against the organization. This means there is a relationship between job satisfaction with income, promotion, working conditions, supervision and colleagues. A study was conducted by Rezal et al. (2010) on the comparison of the level of job satisfaction among academic and non-academic staff at Universiti Malaysia Perlis. The respondents involved are 976 non-academic staff while the academic staff is 632 people. However, in this study, only 797 staff were involved. This study aims to determine the extent to which staff is satisfied with the services, operations, and management of UniMAP. Society. The results show significant differences in the domain of job satisfaction among academic and non-academic staff.

Further studies conducted by Sabharwal \& Corley (2009) related to faculty job satisfaction on gender and discipline. This study aims to identify and compare job satisfaction among faculty employees in research institutions by looking at gender differences and disciplines, namely science, social sciences, engineering and health. Previous studies have focused a lot on job satisfaction in the faculty, and very few have studied gender and disciplinary differences. For example, most studies on job satisfaction by gender only focus on pure science and engineering (Callister, 2006: Ginther, 2004; Long, Allison \& Mc Ginnis, 1993). Issues related to faculty job satisfaction, retention and seriousness will be necessary for university administration and education policymakers. Studying job satisfaction at the university is necessary because there are always social and intellectual structures. This study obtained data from the 2003 Survey of Doctorate Recipients collected twice a year and received funding from the National Science Foundation (NSF 2003 SDR). The overall results show that female faculty members have a low level of job satisfaction than male faculty members based on disciplinary differences. This indicates that there is a difference in job satisfaction between men and women in the faculty. In addition, among female faculty members, engineers have a higher level of job satisfaction and male members in the faculty of social scientists have high job satisfaction. This study's results are supported by a study made by Ward \& Sloane (2000), stating that female engineers have higher job satisfaction than social scientists with low job satisfaction among female members in the 
faculty. The importance of salary factors on job satisfaction and job dissatisfaction is a controversial aspect. According to Herzberg et al. (1959), the salary factor is in seventh place compared to 13 other factors that influence job satisfaction. Nash (1985) found that of the ten factors that affect job satisfaction, salary ranks fifth for men while seventh place for women. This study is supported by the study of Zabid et al. (1990) who found that high-paid workers were more satisfied with their work compared to low-wage workers.

Adkins et al. (2001) found that the length of service period among faculty members significantly impacted job satisfaction. The results of this study are also similar to the study conducted by Bender \& Haywood (2006) who concluded that the duration of work service between faculty members has high job satisfaction compared to new and non-permanent faculty members. Another study conducted by Austin (1985) on male administrators and female administrators working at universities in the United States. The study involved 260 subjects. The findings of the study also show that female administrators experience higher job satisfaction compared to male administrators. Similarly, D'Arcy et al. (1984) found that female workers showed higher job satisfaction than male workers. A study conducted by Sidek and Mardiana (1999) related to employee job satisfaction among administrative officers of Universiti Putra Malaysia (UPM) aim to determine whether it exists the relationship between aspects of job satisfaction such as work environment, promotion opportunities, salaries, supervision and colleagues with job satisfaction among UPM administrative officers. The study subjects consisted of 55 administrative officers on duty using simple random sampling. The instrument used is the Job Descriptive Index (JDI), which was translated into English by Zainal (1980) using the back translation. The data obtained were analyzed using descriptive statistics, simple regression and multiple regression at the 0.05 level. The results show a correlating influence between work environment, promotion opportunities, salary, supervision and colleagues with job satisfaction. The study results also show that each of these aspects has a significant influence on job satisfaction.

A study was conducted abroad entitled job satisfaction among women in the United Arab Emirates (UAE) with 1272 employees. This study aims to examine the factors that contribute to job satisfaction to public and private employees. Nearly $50 \%$ of employees are married, $45 \%$ are unmarried and $4 \%$ are divorced and $1 \%$ are widows. The regression results show that three factors increase job satisfaction, namely age, education and income. The results show that there is a significant positive relationship between job satisfaction and age. In comparison, women workers with a high level of education are more satisfied than women with a low education level. For women who earn high salaries have higher job satisfaction than employees who earn low wages. Promotion is an integral part of an individual's career. Power, status, responsibility, salary and incentives are also increased in line with promotion. An employee is usually given a promotion based on job performance, level of education, experience, length of service, support of superiors, and even health reports. Herzberg et al. (1959), after doing 16 studies on job satisfaction, found that promotion opportunities are the third factor that is considered essential to get job satisfaction. 
Some studies show a positive association of job satisfaction with service duration. A study made by Ronen (1978) found that employees are satisfied with their work in the first year and less job satisfaction when reaching the service period from two to five years. However, after six years, their job satisfaction increases again. These findings are supported by Khaleque et al. (1987), who found that employees who worked for more than five years were more satisfied with their work than employees who worked less than five years. According to Muzita (1986), age factors can influence job satisfaction. Based on his study, workers under the age of 30 are less satisfied with work and are more likely to change jobs than employees over 30. This is because the level of satisfaction for the elderly has reached the maximum level of satisfaction. This view is supported by Berkowitz et al. (1987), workers over the age of 40 are more satisfied with the rewards received.

\section{Depression, Anxiety and Stress Among Teachers}

Desouky \& Allam (2017) have conducted a study on work stress, anxiety and depression among teachers in Egypt. Occupational stress (OS) among teachers causes depression and anxiety. This study aims to assess the prevalence of OS, depression and anxiety among Egyptian teachers. The respondents of this cross-sectional study were 568 Egyptian teachers. Respondents filled out a questionnaire on personal data. The Arabic version of the Occupational Stress Index (OSI), the Arabic version validated by Taylor, indicates anxiety and the Beck Depression Inventory (BDI) was used to assess OS, anxiety and depression. OS prevalence, anxiety and depression among teachers were $(100 \%, 67.5 \%$ and $23.2 \%)$, respectively. Results found that total OS scores, anxiety and depression were significantly higher among teachers over 40, female teachers, primary school teachers, those with insufficient salaries, higher teaching experience, higher qualifications and higher workload. Low positive correlations were found between OS scores and anxiety and depression scores. Kidger, Brockman et al. (2016) have studied teacher well-being and depressive symptoms, and other factors in English secondary schools. Teachers have been shown to have high levels of stress and mental disorders. However, several studies have examined factors in the school environment related to teachers' poor mental health. The sample of this study was conducted on 555 teachers in 8 schools in Bristol. The results of the study found a weak and insignificant relationship between teacher well-being and depressive symptoms. The average teacher well-being (SD) score (47.2 (8.8)) was lower than reported in the working population sample, and $19.4 \%$ had moderate to severe depressive symptoms (PHQ-9> ten scores) and depressive symptoms (ORs range from $2.44[1.41,4.19]$ to 3.31 [1.70, 6.45]). Low well-being and high symptoms of depression among teachers. Interventions aimed at improving their mental health may reduce work-related stress and increase the support available to them.

A study was conducted by Jawahir (2009), which aims to identify the level of satisfaction and its relationship with demographic characteristics such as age, income and length of service with job satisfaction among Assistant Teachers of Subjects (GKMP) secondary schools in Jasin and Melaka Tengah districts. The respondents involved consisted of 104 GKMP people from 30 schools. The study's findings show that the majority of GKMPs feel dissatisfied with their careers in upholding the teaching profession. The study's findings show that the demographic characteristics of GKMP have significant relevance to the level probability 0.05 with job satisfaction among GKMP. Based 
on the findings of the study, among the suggestions that can be implemented by the Department of Education and the Ministry of Education Malaysia is to identify the need for rewards that match the workload of the defense for a more secure future and more open opportunities for all GKMP to be able to compete in generating human capital development.

The study of the relationship between gender and job satisfaction is a frequent aspect. Sutter M.R (1996) has used the measurement tool "Minnesota Satisfaction Questionnaire" to predict the job satisfaction of senior secondary school teachers. A total of 335 men and 81 women from Ohio High School, USA were involved. The study's findings show that the job satisfaction of female Senior Assistant teachers is higher than male Senior Assistant teachers. Borg et al. (1991) found that teachers who reported tensions were less satisfied with the work of teaching, always skipped, and were more interested in leaving the profession and would never teach again. Friedman's (1992) study shows that teachers need job satisfaction to avoid "burnout." This shows how vital job satisfaction in an organization needs to be identified.

\section{Methods}

This study was conducted to look at the extent of the relationship between stress, depression, and anxiety with special education teachers' job satisfaction. To achieve the above purpose, this study used a cross-sectional research method and applied the questionnaire technique, a survey method to collect quantitative data because it is more suitable for obtaining significant research results. Ninety-six school teachers have participated in this research. The 96 participants came from various Kuala Lumpur schools, including Setapak, Genting Klang, Kampung Baru, and Jalan Raja Laut. Several psychological tests were used in this research. Depression, Anxiety and Stress (DASS-21) and Job Satisfaction Survey (JSS) were used to measure the variables in this research.

\section{Results and Discussion}

This study examines the Stress, Depression and Anxiety and Job Satisfaction of teachers in three schools in Kuala Lumpur. Among the schools is Sekolah Kebangsaan Pendidikan Khas Kg. Baharu, Jalan Batu (B) Special Education School and Setapak Special Education National Secondary School, Kuala Lumpur. This study also outlines several approaches to facilitate measuring the relationship between Stress, Depression and Anxiety and Job Satisfaction. Job satisfaction is measured by answering questions related to appreciation, fairness, marketability, and salary and rank. These stress, depression and anxiety are broken down into three dimensions, namely stress, depression and anxiety. These two aspects are combined and formulated into a set of questionnaires containing 57 questions excluding the respondents' demographic section. Then this questionnaire was distributed to teachers through hard copy and online copy.

This questionnaire was distributed to 128 special education teachers who teach in three schools, namely Sekolah Kebangsaan Pendidikan Khas Kg. Baharu, Jalan Batu (B) Special Education School and Setapak Special Education National Secondary School, Kuala Lumpur. However, only 96 questionnaires answered by teachers can be cited due to some constraints. Among the unavoidable constraints is the Movement Control Order (PKP) in dealing with Coronavirus outbreak (covid-19). All economic and social activities are closed, including all schools. This issue 
caused the researcher not to be able to collect all the data of the respondents. All teachers cooperated well in conducting this study. This study initially wanted to examine the education teachers in schools around Kuala Lumpur as a whole. This study involved 23 male respondents and 73 female respondents. This shows women dominate the current teacher population and many men do not choose to be teachers. This can also be a factor where there is an internal conflict when female teachers in schools are not given more recognition compared to male teachers easily absorbed into the organization of the education office or education department. This is also the main reason female teachers find it challenging to move around compared to male teachers.

The respondents' age level is dominated by $41-50$ years, which is a total of 44 respondents. In addition, there are 22 respondents aged 51- 60 years, followed by 18 respondents aged 31-30 years and 12 respondents aged 21-30 years. The main factor in reducing the rate of stress, depression and anxiety is the respondents' salary. Most of the respondents in this study are 41 years old and above. At this stage, respondents experience a more stable and affordable salary because they have worked for more than ten years. The respondents of this study are mostly married. There are no respondents with widower status but there are two female respondents with widow status. A total of 84 respondents were married and a total of 10 respondents were single and unmarried despite the age of 30. Based on the study's findings on stress, depression and anxiety can be predicted that married respondents have stable levels of stress, depression and anxiety and do not interfere with life function. Some data shows a slight improvement in aspects of stress management, depression and anxiety but the majority states that they are at a low level of stress, depression and anxiety.

Education level can also play a role in job satisfaction and aspects of stress management, depression and anxiety. Most of the respondents in this study have graduated with a bachelor's degree, a total of 77 respondents. In addition, 14 respondents are diploma graduates, followed by five respondents who completed their studies up to undergraduate. When the field of study is suitable for the job, it will increase job satisfaction and lower stress, depression and anxiety. The respondents of this study have a high level of education that helps them handle daily tasks and recognize and manage their stress. The last aspect studied in the respondents' demographic section in this study is the average salary received by the respondents. Among the reasons for studying financial respondents is because the higher a person's financial strength, the lower the stress rate, the higher the job satisfaction felt. It can once be proven when almost half that is a total of 41 respondents have an average salary of RM5001 and more. When finances increase it will give high motivation in carrying out work. Next, a total of 42 respondents received an average salary of RM 3001 to RM 4000. The respondents' lowest salary was RM 1001 to RM 3000 which is a total of 13 respondents.

The average mean achieved in terms of stress, depression and anxiety is 32.36 while for the aspect of job satisfaction the average mean achieved 133.21. The midpoint, better known as the median for stress, depression and anxiety, and job satisfaction, is 30.50 and 131.00 . In this study, the researcher found that the minimum value for stress, depression, and anxiety is 21 . For the 
aspect of job satisfaction, the respondents' minimum value is 72 . For the maximum value for stress, depression and anxiety, the average value obtained is 71 and for job satisfaction is 192. Next, the researcher has also conducted a normality test to study if this study's data is in the normal distribution. The normal distribution is identified by examining skewness and kurtosis values with values between 33 to 3 . The results of the normality distribution indicate that the data obtained are typically distributed. Stress, depression and anxiety variables obtained values of 1.422 and 2.813 for skewness and kurtosis. For the job satisfaction variable, the skewness value obtained is 0.080 and the kurtosis value is 0.981 .

The rate of stress, depression, and anxiety of special education teachers in Kuala Lumpur is high.

This hypothesis is built based on the reading and research of articles conducted by researchers. Based on this article's reading and research, it is said that the stress rate, depression, and anxiety of special education teachers will increase from time to time when there are various types of challenges in the workplace. Teachers will feel lifeless and less active in doing activities due to the rate of stress, depression and anxiety that are not smart.

Special education teachers are also said to have high levels of stress, depression and anxiety due to internal conflicts and overwork. In addition, teachers' ability to know and manage the rate of stress, depression, and anxiety is quite tricky when they always need to be sensitive and think about their situation, exceptional education students in school. This is because these students need high support from the teacher so the teacher forgets to take care of himself to protect his students' interests.

\section{The level of job satisfaction of special education teachers in schools around Kuala Lumpur is high.}

This hypothesis is built based on the reading and research of articles conducted by researchers. Based on this article's reading and research, it is said that the level of job satisfaction of a teacher will decrease from time to time when there are various types of constraints in the workplace. Among the constraints that exist in the workplace is the lack of support from the administration, dealing with students, finances, relationships with colleagues and overwork. Based on the researcher's research, the level of job satisfaction is low due to teachers' problems such as excessive assignments. Teachers are now required to do various filing work to meet the school and the education office's needs. When filing work is not done correctly, it will cause them to face various headmasters or outside officials' questions.

The hypothesis presented by the researcher in this study is that the high level of job satisfaction is rejected because the frequency distribution of job satisfaction in this study is in a moderate condition of 60 respondents. Only ten respondents stated that they were in a low level of job satisfaction and 26 respondents stated that they were in a high level of job satisfaction. Researchers found that the elements that lead to job satisfaction are a lack of support from the administration that does not cooperate in performing a task. Respondents at a high level of job satisfaction received good support from the administration and had good relations with 
Vol. 10, No. 1, 2021, E-ISSN: $2226-6348$ @ 2021 HRMARS

colleagues. In addition, respondents at a high level of job satisfaction are due to their financial strength. This is because a total of 41 respondents received a salary of RM 5001 and more.

\section{Job satisfaction does not affect the stress, depression and anxiety of special education teachers in Kuala Lumpur schools.}

Based on the researcher's research and reading from previous articles and findings, job satisfaction affects stress, depression and anxiety among teachers. Researchers have also met and interacted with some teachers who work in primary schools where teachers feel stressed about their working conditions. Therefore, the researcher took the initiative to study the rate of stress, depression and anxiety and job satisfaction among special education teachers in schools around Kuala Lumpur. Researchers have also read articles that have been formulated about stress rates, depression and anxiety and job satisfaction, where those articles state that there is a significant relationship between these two variables. Job satisfaction in this workplace causes increased stress, depression and anxiety and impacted the quality of their work.

The findings show no relationship between job satisfaction and stress rates, depression and anxiety and the hypotheses that have been constructed have been rejected. There was no significant relationship between the two variables of this study. Stress, depression, and anxiety rates in this study were high, while job satisfaction in this study was moderate. Thus, there is no element that can cause a decrease in the rate of stress, depression and anxiety that has caused the level of stress, depression and anxiety to be at a high level.

The researcher also found that the respondents who were respondents for this study got an adequate salary, high support, and good relationship with colleagues, resulting in no significant relationship between job satisfaction variables with stress, depression, and anxiety. The study's findings indicate that the level of stress, depression, and anxiety of teachers is at a low level. So it can be said that teachers can recognize and manage low emotions and have useful social competence and skills. The study's findings also concluded that the level of job satisfaction of teachers is at a moderate level. Some have a high level of job satisfaction but the highest frequency is at a moderate level. This shows that there is job satisfaction among teachers but they can deal with the problems faced. And lastly, the study's findings indicate that there is no significant relationship between the two variables studied. Job satisfaction does not affect the level of stress, depression, and anxiety of teachers. Thus, it is concluded that these variables do not affect each other.

\section{Conclusion}

In conclusion, the correlation between depression, anxiety and stress rate with job satisfaction is moderate. This shows that depression, anxiety and stress rate do not affect job satisfaction among teachers in three schools in Kuala Lumpur. There was no significant relationship between the variables of stress, depression and anxiety with job satisfaction. Based on the study's findings, the researcher found that this study needs to be done as a whole in Malaysia to get a broader picture and help the relevant organisations to identify the state of stress, depression, and anxiety with teacher job satisfaction. The involvement of teachers also plays a high role in the success of 
Vol. 10, No. 1, 2021, E-ISSN: 2226-6348 @ 2021 HRMARS

such studies. The findings of this study are a platform so that improvements can be made for future research. It is possible that in future studies, researchers can use independent variables that are aspects of motivation by looking at their relationship with other dependent variables.

\section{References}

Abdul Aziz, M. H., \& Udin, A. (2012). Kesihatan Mental Di Kalangan Guru Di Sekolah Menengah Di daerah Kerian, Perak (Doctoral dissertation, Universiti Teknologi Malaysia).

Adey, N. H., \& Bahari, F. H. (2010). Hubungan antara kecerdasan emosi, kepuasan kerja dan komitmen terhadap organisasi. Jurnal Kemanusiaan, 8(2).

Affendi, F. (2014). Tahap kepuasan kerja dan komitmen organisasi dalam kalangan guru kolej vokasional: pendekatan structural equation model(Doctoral dissertation, Universiti Tun Hussein Onn Malaysia).

Afiq, A. (2015). Hubungan Diantara Bidang Kehidupan Bekerja dan, Personaliti Terhadap Burnout Dalam Kalangan Guru Sekolah. Jurnal Psikologi UKM.

Ambotang, A. S., Pilus, N., Andin, C., \& Abdullah, N. Q. (2014). Hubungan Kerenah Pelajaran Dan Beban Tugas Dengan Tahap Stres Guru Di Sekolah Menengah. Jurnal Kinabalu,20.

Aziz, K. A., \& Hussin, F. (2017). Pengaruh iklim organisasi terhadap kepuasan kerja guru di Sekolah Menengah dalam Daerah Kuala Terengganu. Proceedings of the ICECRS, 1(1).

Bar-On, R. (1997). BarOn Emotional quotient inventory. Multi-Health Systems. Bokti, N. L. M., \& Talib, M. A. (2010). Tekanan kerja, motivasi dan kepuasan kerja tentera laut armada tentera laut diraja Malaysia. Jurnal Kemanusiaan, 8(1).

Bottesi, G., Ghisi, M., Altoè, G., Conforti, E., Melli, G., \& Sica, C. (2015). The Italian version of the Depression Anxiety Stress Scales-21: Factor structure and psychometric properties on community and clinical samples. Comprehensive Psychiatry, 60, 170-181.

Hong, C. O., \& Ismail, A. (2017). Sokongan Pihak Pengurusan Terhadap Kerja Guru di Sekolah Kebangsaan Dan Sekolah Jenis Kebangsaan Cina. JuPiDi: Jurnal Kepimpinan Pendidikan, 2(2), 42-57).

Dave, S., Parikh, M., Vankar, G., \& Valipay, S. K. (2018). Depression, anxiety, and stress among resident doctors of a teaching hospital. Indian Journal of Social Psychiatry, 34(2), 163.

Daza, P., Novy, D. M., Stanley, M. A., \& Averill, P. (2002). The depression anxiety stress scale-21: Spanish translation and validation with a Hispanic sample. Journal of Psychopathology and Behavioral Assessment, 24(3), 195-205.

Dhania, D. R. (2010). Pengaruh Stres Kerja, Beban Kerja, terhadap kepuasan Kerja (studi pada medical representatif di Kota Kudus).Jurnal Psikologi: PITUTUR, 1(1), 15-23.

Dhermawan, A. A. N. B., Sudibya, I. G. A., \& Utama, I. W. M. (2012). Pengaruh motivasi, lingkungan kerja, kompetensi, dan kompensasi terhadap kepuasan kerja dan kinerja pegawai di lingkungan kantor Dinas Pekerjaan Umum Provinsi Bali. Jurnal Manajemen, Strategi Bisnis, dan Kewirausahaan, 6(2), 173-184.

Doraisamy, G. S. (2007). Hubungan Tekanan Kerja dan Kepuasan Kerja dengan Komitmen Terhadap Organisasi: Satu Kajian di Ibu Pejabat Jabatan Kerja Raya Malaysia (Doctoral dissertation, Universiti Utara Malaysia).

Dunham, J. (1992). Stress in Teaching. Edisi Kedua. London: Routledge. 
Dunham, J. (1976). Stress Situations and responses in National Association of Schoolmasters (Ed.). Stress in schools. Hemel Hempstead: National Association of Schoolmasters.

Gold, Y., Dan Roth, R. A. (1993). Teachers Managing Stress and Preventing Burnout - The Professional Health Solution. London: The Falmer Press.

Hamid, R., Ali, S. K. S., Daud, M. A. K. M., Zulnaidi, H., \& Hamid, Z. (2019). Keberkesanan Lima Minit Senaman Qigong Terhadap Tahap Kemurungan, Kebimbangan Dan Stres Dalam Kalangan Murid Tingkatan Empat. JuPiDi: Jurnal Kepimpinan Pendidikan, 6(4), 61-80.

Henry, J. D., \& Crawford, J. R. (2005). The short-form version of the Depression Anxiety Stress Scales (DASS-21): Construct validity and normative data in a large non-clinical sample. British journal of clinical psychology, 44(2), 227-239.

Huang, C. J., Webb, H. E., Zourdos, M. C., \& Acevedo, E. O. (2013). Cardiovascular reactivity, stress, and physical activity. Frontiers in physiology, 4, 314.

Isa, F. M., Ismail, R., \& Hassan, N. (2018). Peranan Sokongan Sosial terhadap Kemurungan dalam kalangan Remaja Penagih Dadah (The Role of Social Support towards Depression among Adolescent Drug Addicts). Jurnal Psikologi Malaysia, 32(3).

Jantan, S. (2009). Tahap stres dan tahap kepuasan kerja dalam kalangan pensyarah Universiti Teknologi Malaysia (Doctoral dissertation, Universiti Teknologi Malaysia).

Jari, I. (2014). Pengaruh perilaku kepimpinan pengetua ke atas tekanan kerja guru sekolah menengah di Melaka/Ibrahim bin Jari (Doctoral dissertation, University of Malaya).

Jazmi, M. I. (2009). Gaya kepimpinan pengetua dan kepuasan kerja guru: kajian perbandingan antara SMKA dengan SMK (Doctoral dissertation, Universiti Utara Malaysia).

Kim, T. S. (2006). Stres Kerja di Kalangan Guru Aliran Teknik di Sekolah Menengah Teknik Negeri Johor, Melaka dan Negeri Sembilan.UTM, Skudai. Projek Sarjana. Tidak Diterbitkan.

Kinnunen, U. (1989). Teacher Stress over a School Year. Jyvaskyla: University of Jyvaskyla.

Kyriacou, C. (1987). Teacher Stress and Burnout: An International Review. Educational Research. 29: 146-152.

Lester, N., Nebel, L. E., \& Baum, A. (1994). Psychophysiological and behavioral measures of stress. In Stress and mental health (pp. 291-314). Springer, Boston, MA.

Lineker, T., \& Ferlis, B. (2016). Mixture of anxiety and depression among parents of physical disabled children in rural Sabah. [Campuran kebimbangan dan kemurungan dalam kalangan ibu bapa kanak-kanak kurang upaya fizikal di luar bandar Sabah]. Jurnal Psikologi Malaysia, 30, 61-73.

Ling, W. Y. (2007).Kepuasan kerja guru-guru aliran Pendidikan Teknikal dan Vokasional di sekolah-sekolah Menengah Teknik di negeri Johor Darul Takzim (Doctoral dissertation, Thesis: Universiti Teknologi Malaysia).

Mahan, P. L., Mahan, M. P., Park, N. J., Shelton, C., Brown, K. C., \& Weaver, M. T. (2010). Work environment stressors, social support, anxiety, and depression among secondary school teachers. AAOHN Journal, 58(5), 197-205.

Mohd, A. (2004). Faktor-faktor yang mempengaruhi kepuasan kerja guru dalam bidang teknik dan vokasional berdasarkan teori Maslow di sekolah akademik di daerah Pasir Puteh, Kelantan(Doctoral dissertation, Universiti Teknologi Malaysia).

Ferqdaus, M. (2016). Kemurungan, Kebimbangan, Stres, dan Kesejahteraan Psikologi dalam kalangan Pelajar Permata Pintar dan Sekolah Berasrama Penuh. Jurnal Psikologi UKM. 
Norhidayu, A. (2018). Hubungan Tahap Kemurungan, Kebimbangan dan Tekanan dengan Kepuasan Kerja dalam kalangan Pekerja di Fakulti Kejuteraan Elektrik (FKE), UITM Shah Alam, Jurnal Psikologi UKM.

Asmida, N. (2017). Pengaruh Resilien, Strategi Daya Tindak Terhadap Kesejahteraan Psikologi dalam kalangan pekerja di Malaysia. Jurnal Psikologi UKM.

Panatik, S. A., \& Badri, S. K. Z. (2012). Konflik kerja-keluarga, kesihatan mental dan kecenderungan tukar ganti kerja dalam kalangan guru. Sains Humanika, 59(1).

Schmidt, D. R. C., Dantas, R. A. S., \& Marziale, M. H. P. (2011). Anxiety and depression among nursing professionals who work in surgical units. Rev Esc Enferm USP, 45(2), 487-93.

Travers, C. J., \& Cooper, C. L. (1993). Mental health, job satisfaction and occupational stress among UK teachers. Work \& Stress, 7(3), 203-219.

Tugimin, A. J., Saadan, R., \& Husain, K. (2011). Kesan Komunikasi Dalam Organisasi Ke Atas Kepuasan Kerja Staf Sokongan Di Universiti Teknikal Malaysia Melaka (Utem)(The Effect Of Organizational Communication On The Job Satisfaction Of Support Staff In Universiti Teknikal Malaysia Melaka (UTeM)). Journal of Human Capital Development (JHCD), 4(2), 5774.

Veloo, A., \& Zolkepli, W. H. (2011). Atribut sistem penilaian prestasi dengan kepuasan kerja dalam kalangan guru. International Journal of Management Studies (IJMS), 18(1), 197-216.

Werang, B. R. (2014). Pengaruh kepemimpinan transformasional kepala sekolah, moral kerja guru, dan kepuasan kerja terhadap kinerja guru SDN di Kota Merauke. Jurnal Cakrawala Pendidikan, 33(1).

Yang, X., Ge, C., Hu, B., Chi, T., \& Wang, L. (2009). Relationship between quality of life and occupational stress among teachers. Public health, 123(11), 750-755. 